\title{
Seroepidemiology of Leishmania spp. in dogs residing in Telêmaco Borba, Paraná, Brazil
}

\section{Soroepidemiologia da Leishmania spp. em cães do Município de Telêmaco Borba, Paraná, Brasil}

\author{
Caroline Constantino $^{1 *}$; Aline Kuhn Sbruzzi Pasquali²; Eloiza Teles Caldart ${ }^{3}$; \\ Fernanda Pinto Ferreira ${ }^{3}$; Elizabete Regina Marangoni Marana ${ }^{4}$; \\ Roberta Lemos Freires; Regina Mitsuka-Breganó ${ }^{6}$; Carmen Lúcia Scortecci Hilst ${ }^{5}$; \\ Odilon Vidotto $^{5}$; Italmar Teodorico Navarro ${ }^{5}$
}

\begin{abstract}
Leishmaniasis is an important metazoonosis caused by protozoa of the genus Leishmania and has a heteroxenic life cycle involving invertebrate and vertebrate hosts. Transmission occurs during the blood meal of infected phlebotomine sand flies in wild species, domestic animals, and humans. The dog is a reservoir for the parasite causing visceral leishmaniasis (VL), whereas in American tegumentary leishmaniasis (ATL), dogs are erratic hosts that are accidentally infected, as in humans. Dogs are considered an important indicator of the parasite and its vectors in the environment, thus highlighting the importance of diagnosis in these animals. This study aimed to assess the seroepidemiology of Leishmania spp. in dogs in the municipality of Telêmaco Borba that were part of a castration campaign. Blood samples from 191 dogs were collected, and their owners were surveyed on various epidemiological variables. Serological analysis was performed using indirect immunofluorescence (IIF) and rapid immunochromatography (DPP $®$ ). Screening by IIF identified $13(6.81 \%)$ positive animals, none of which were positive for the DPP ${ }^{\circledR}$ test, which is specific for VL. Statistical analysis of the questionnaire responses indicated a significant association between seropositivity and the presence of stacked or composting leaves in the backyard $(p=0.0498)$, forest areas (squares, woods, parks) near the residence $(\mathrm{p}=0.0015)$, and poorly healing ulcerated or nodular epidermal lesions in the $\operatorname{dog}(\mathrm{p}=0.0138)$. This study revealed the presence of anti-Leishmania spp. IgG antibodies in dogs residing in Telêmaco Borba, suggesting the presence of the parasite and vector in the environment. In addition, the existence of stacked or composting leaves in the backyard, forest areas near the residence, and epidermal lesions in dogs are factors associated with Leishmania spp. infection in pet dogs.
\end{abstract}

Key words: Leishmaniasis, pet dogs, epidemiology, indirect immunofluorescence, rapid immunochromatography test, diagnosis

\footnotetext{
${ }^{1}$ Discente do Curso de Graduação em Medicina Veterinária, Universidade Estadual de Londrina, UEL, Londrina, PR, Brasil. E-mail: caroline.const@hotmail.com

${ }^{2}$ Discente do Curso de Mestrado em Ciência Animal, DMVP, UEL, Londrina, PR, Brasil. E-mail: alinesbruzzi@gmail.com

${ }^{3}$ Residentes em Zoonoses e Saúde Pública, DMVP, UEL, Londrina, PR, Brasil. E-mail: eloiza.vet@gmail.com; nandaferreiravet@ gmail.com

${ }^{4}$ Técnica de nível superior, Laboratório de Zoonoses e Saúde Pública, DMVP, UEL, Londrina, PR, Brasil. E-mail: ermarana@uel.br

${ }_{5}^{5}$ Profs. Drs., Dept ${ }^{\circ}$ de Medicina Veterinária Preventiva, UEL, Londrina, PR, Brasil. E-mail: rlfreire@uel.br; chilst@uel.br; vidotto@uel.br; italmar@uel.br

${ }^{6}$ Prof $^{a}$, Dept ${ }^{\circ}$ de Ciências Patológicas, UEL, Londrina, PR, Brasil. E-mail: rbregano@uel.br

* Author for correspondence
} 


\section{Resumo}

A leishmaniose é uma importante metazoonose causada por protozoários do gênero Leishmania, com ciclo de vida heteroxênico que envolve hospedeiros invertebrados e vertebrados. A transmissão ocorre durante o repasto sanguíneo do flebotomíneo infectado em animais domésticos e silvestres e no homem. O cão é caracterizado como reservatório do protozoário na leishmaniose visceral, já na leishmaniose tegumentar americana é um hospedeiro errático que, assim como o homem, se infecta acidentalmente. $\mathrm{O}$ cão ainda pode ser considerado um importante sinalizador da presença do protozoário e dos vetores no ambiente, assinalando assim a importância do diagnóstico nestes animais. Este trabalho teve como objetivo conhecer a soroepidemiologia da Leishmania spp. em cães do Município de Telêmaco Borba que participaram de um mutirão de castração. Foram coletadas amostras de sangue de 191 cães e aplicado um questionário epidemiológico a seus proprietários. A análise sorológica foi realizada pelas técnicas Imunofluorescência Indireta (IFI) e Imunocromatografia rápida (DPP $®)$. A triagem realizada pela IFI revelou $13(6,81 \%)$ animais reagentes, destes nenhum apresentou positividade no teste $\mathrm{DPP}{ }^{\circledR}$, específico para leishmaniose visceral. A análise estatística das variáveis presentes no questionário epidemiológico indicou associação significativa entre a sorologia positiva e presença de folhas amontoadas/compostagem no quintal $(\mathrm{p}=0,0498)$, áreas de mata (praças, bosques, parques) nos arredores da residência $(\mathrm{p}=0,0015)$ e lesões ulceradas e/ou nodulares de difícil cicatrização na pele de animais $(\mathrm{p}=0,0138)$. Este estudo revelou que há anticorpos IgG anti-Leishmania spp. em cães do Município de Telêmaco Borba, sugerindo a presença do protozoário e do vetor no ambiente, e que a existência de folhas amontoadas/compostagem no quintal, áreas de mata nos arredores da residência e lesões na pele de animais são fatores associados à infecção por Leishmania spp. nestes cães.

Palavras-chave: Leishmaniose, cães domiciliados, epidemiologia, Imunofluorescência indireta, Teste de Imunocromatografia rápida, diagnóstico

\section{Introduction}

Leishmaniasis is a metazoonosis of great concern in public health that results from parasitism by protozoa of the genus Leishmania. This parasite has a heteroxenic life cycle involving both invertebrate hosts in the Phlebotominae (sandflies) subfamily and vertebrate mammalian hosts such as humans, wild animals, and domestic animals (ARRUDA, 2010; BRASIL, 2007). The protozoan has two distinct morphological forms: the infective promastigote form residing in the digestive tract of the sandfly and the amastigote form that infects cells of the mononuclear phagocytic system in vertebrate hosts (PESSÔA; MARTINS, 1988). The condition has various clinical forms that can compromise the skin, mucosa, and viscera, depending on the specific parasite and the host immunity (BRASIL, 2010a, 2010b).
Leishmaniasis is a neglected disease with a worldwide distribution restricted to tropical and temperate regions inhabited by the insect vectors. It primarily affects the poorest countries, especially developing countries, and is endemic in 88 countries; approximately 2 million new cases occur annually, and 350 million people worldwide are at risk of contracting the disease (WHO, 2012). Approximately $90 \%$ of visceral leishmaniasis (VL) cases occur in Brazil, Ethiopia, Bangladesh, India, Nepal, and Sudan. Brazil is also among the 12 countries with $90 \%$ of all American tegumentary leishmaniasis (ATL) cases worldwide (CDC, 2010; WHO, 2010, 2012).

Due to human activities impacting the environment, the pattern of leishmaniasis transmission has changed slightly over time. Formerly, transmission occurred primarily in rural and suburban environments, but it has recently 
encroached into urban centers, semidomestic, and domestic environments (BARROS et al., 1985; BRASIL, 2006; TEODORO et al., 1993). With deforestation, road construction, exploitation of forests for extraction and leisure, climate change, and adaptation of vectors to the human environment, there has been rapprochement between the sylvatic and the urban cycles of the disease, and both wild and domestic animals such as dogs have become important in transmission (CASTRO et al., 2002; FALQUETO et al., 1986; GOMES; NEVES, 1998; GONTIJO; MELO, 2004; MARZOCHI; MARZOCHI, 1994; WHO, 2010).

The $\operatorname{dog}$ is a reservoir of the parasite responsible for VL (DANTAS-TORRES, 2009; DEANE, 1956 apud COSTA, 2012; ROMERO; BOELAERT, 2010) and is an important source of infection in sandflies. By contrast, the dog is considered an erratic host for ATL and, like humans, is accidentally infected. Studies have shown that humans who cohabitate with infected symptomatic or asymptomatic dogs were also infected by the protozoan (COUTINHO et al., 1985; FALQUETO et al., 1986; FALQUETO et al., 1991; FALQUETO, 1995; LONARDONI et al., 2006); this highlights the importance of diagnosis in dogs to improve public health and implement control measures.

The municipality of Telêmaco Borba is a favorable environment for the sandfly (vector), and the dog is an important sentinel indicating the presence of the protozoan parasite in the environment. Therefore, the present study aimed to verify the presence of anti-Leishmania spp. IgG antibodies in pet dogs participating in a countywide castration campaign and to determine the factors associated with Leishmania spp. infection in these animals through an epidemiological survey.

\section{Material and Methods}

\section{Study area}

The municipality of Telêmaco Borba is located in the east-central region of the State of Paraná, Brazil, $700 \mathrm{~m}$ altitude, latitude $24^{\circ} 19^{\prime} 26^{\prime \prime} \mathrm{S}$, and longitude 50 36' 56' 'W (IPARDES, 2012). In 2010, the population was 69,872 inhabitants in a 1382.863 $\mathrm{km}^{2}$ area (IBGE, 2012). The city has a subtropical climate with a mean temperature $<18^{\circ} \mathrm{C}$ during the coldest month and $>22^{\circ} \mathrm{C}$ during the hottest month. Summers are hot, frost is infrequent, and most rainfall occurs during the summer months. The mean annual relative humidity is $78.75 \%$ (TELÊMACO BORBA, 2005). The city is surrounded by a large area of reforestation (forestry), which includes the Saltinho Forest Reserve, the Samuel Klabin Ecological Park, and over 85,000 hectares of native forest connected by ecological corridors that provide significant wildlife habitat (TELÊMACO BORBA, 2005).

\section{Sample size and sampling}

Blood samples were collected from 191 dogs of both sexes, various breeds, and ages that participated in the castration campaign. The blood sample was obtained with the written informed consent of the animal's owner and was collected in September and October 2012. This study was approved by the Ethics Committee on Animal Experimentation of the State University of Londrina, protocol number 32/10.

\section{Blood collection from dogs}

Blood was collected from the cephalic or jugular vein with a disposable syringe and needle $(25-\mathrm{G} \times 7)$, and allowed to clot. After removing the clot, the serum was separated and stored at $-15^{\circ} \mathrm{C}$ in a polyethylene $1.5 \mathrm{~mL}$ microtube. 
The dogs were then sedated with acepromazine $(0,05 \mathrm{mg} / \mathrm{kg}$ intravenous $)$ or anesthetized with tiletamine hydrochloride and zolazepan $(0,12 \mathrm{~mL} /$ $\mathrm{kg}$ intravenous).

\section{Indirect immunofluorescence (IIF)}

IIF was performed as described by Oliveira et al. (2008) as a screening tool at the Laboratory of Protozoology, Department of Preventive Veterinary Medicine, State University of Londrina (DMVP-UEL). Promastigotes of Leishmania (Leishmania) amazonensis, conjugated anti-IgG (Sigma Chemical ${ }^{\circledR}$ ), and canine positive and negative controls obtained from animals treated at the Veterinary Hospital of the State University of Londrina were used as antigens. Samples with titers $\geq 40$ were considered reactive.

Rapid immunochromatography for Canine Visceral Leishmaniasis (Dual Path Platform DPP-Canine Visceral Leishmaniasis)

Samples positive on IIF were subjected to rapid immunochromatography (DPP BioManguinhos ${ }^{\circledR}$ ), which is specific for VL, which was analyzed at the Laboratory of Protozoology of DMVP-UEL using the manufacturer's protocol. A 5- $\mu 1$ aliquot of serum was added to the first well, and 2 drops of buffer were added to the same well. After 5 min, the two blue lines corresponding to the control and test samples disappeared. Then, 4 drops of buffer were added to a second well, and the results were read in both wells 10 to $15 \mathrm{~min}$ later. The sample was considered positive if two red lines appeared and negative if only one red line appeared.

\section{Questionnaire and statistical analysis}

The dog owners completed a questionnaire concerning animal identification, origin, feeding, health, housing, and clinical changes in both the animals and humans. The seropositive frequency and the epidemiological variables were compared using the Chi-square $\left(x^{2}\right)$ test corrected by the Yates or Fisher's exact test. The statistical software EpiInfo 3.5.3 was used. The significance level was set at $5 \%$.

\section{Results}

Of $191 \mathrm{dogs}$ evaluated, 13 (6.81\%) were positive for exposure to Leishmania spp. by IIF. Among the reactive samples, $9(69.23 \%)$ had titers of $40,3(23.07 \%)$ of 80 , and $1(7.69 \%)$ of 320 . Of the 13 IIF-seropositive dogs, none was positive on rapid immunochromatography for canine VL, which is used to diagnose ATL.

The frequency of clinical findings in the population was calculated, and the relationship between the epidemiological variables and the presence of anti-Leishmania spp. antibodies detected by IIF were assessed. Seropositivity on IIF was associated with the presence of stacked or composting leaves in the backyard ( $\mathrm{p}=$ 0.0498), forest areas (squares, woods, parks) near the residence $(\mathrm{p}=0.0015)$, and poorly healing ulcerated or nodular epidermal lesions on the dogs $(\mathrm{p}=0.0138$, Table 1$)$. 
Table 1. Association between epidemiological variables and the presence of anti-Leishmania spp. IgG, by indirect immunofluorescence (IIF) in 191 dogs from Telêmaco Borba, Paraná, 2013.

\begin{tabular}{|c|c|c|}
\hline Epidemiological variable & Number seropositive/Total* (\%) & $p$-Value \\
\hline \multicolumn{3}{|l|}{ Gender } \\
\hline Male & $4 / 63(6.3)$ & 0.8969 \\
\hline Female & $9 / 128(7.0)$ & \\
\hline \multicolumn{3}{|l|}{ Race } \\
\hline No defined breed & $12 / 180(6.7)$ & 0.7591 \\
\hline Defined breed & $1 / 11(9.1)$ & \\
\hline \multicolumn{3}{|l|}{ Age } \\
\hline Less than 1 year & $3 / 47(6.4)$ & \\
\hline Between 1 and 8 years & $9 / 138(6.5)$ & 0.8409 \\
\hline Greater than 8 years & $1 / 6(16.7)$ & 0.9451 \\
\hline Residence type & & 0.8800 \\
\hline Urban & $13 / 180(7.2)$ & 0.7591 \\
\hline Suburban & $0 / 11(0)$ & \\
\hline \multicolumn{3}{|c|}{ Dog lived in another city $>1$ year previously } \\
\hline Yes* & $1 / 3(33.3)$ & 0.4943 \\
\hline No & $12 / 188(6.4)$ & \\
\hline \multicolumn{3}{|c|}{ Dog travelled in the past 6 months } \\
\hline Yes* & $1 / 1(100)$ & 0.0855 \\
\hline No & $12 / 190(6.3)$ & \\
\hline \multicolumn{3}{|l|}{ Diet } \\
\hline Commercial product & $4 / 81(4.9)$ & 0.5559 \\
\hline Home cooked or mixed & $9 / 110(8.2)$ & \\
\hline \multicolumn{3}{|c|}{ Contact between dog and wild animals } \\
\hline Yes & $0 / 2(0)$ & 0.3063 \\
\hline & $13 / 189(6.9)$ & \\
\hline \multicolumn{3}{|c|}{ Contact between dog and domestic animals } \\
\hline Yes & $8 / 90(8.9)$ & 0.4289 \\
\hline No & $5 / 101(5)$ & \\
\hline \multicolumn{3}{|c|}{ Contact between dog and rodents } \\
\hline Yes & $2 / 12(16.7)$ & 0.4185 \\
\hline No & $11 / 179(6.1)$ & \\
\hline \multicolumn{3}{|l|}{ Waste disposal } \\
\hline Public collection & $13 / 190(6.8)$ & 0.0855 \\
\hline \multirow{2}{*}{\multicolumn{3}{|c|}{$\begin{array}{l}\text { Waste pile } \\
\text { Organic matter in backyard }\end{array}$}} \\
\hline & & \\
\hline Yes & $13 / 150(8.7)$ & 0.1090 \\
\hline & $0 / 41(0)$ & \\
\hline \multicolumn{3}{|c|}{ Stacked leaves or compost in backyard } \\
\hline Yes & $6 / 40(15)$ & 0.0498 \\
\hline No & $7 / 151(4.6)$ & \\
\hline \multicolumn{3}{|l|}{ Debris in backyard } \\
\hline Yes & $1 / 16(6.3)$ & 0.6700 \\
\hline No & $12 / 175(6.9)$ & \\
\hline \multicolumn{3}{|c|}{ Sand, dirt, grass or garden in backyard } \\
\hline Yes & $11 / 119(9.2)$ & 0.1548 \\
\hline No & $2 / 72(2.8)$ & \\
\hline \multicolumn{3}{|c|}{ Vegetable garden or orchard in backyard } \\
\hline Yes & $2 / 35(5.7)$ & 0.9303 \\
\hline No & $11 / 156(7.1)$ & \\
\hline
\end{tabular}




\begin{tabular}{|c|c|c|}
\hline Epidemiological variable & Number seropositive/Total* (\%) & $p$-Value \\
\hline \multicolumn{3}{|c|}{ Waste pile adjacent to residence } \\
\hline Yes & $4 / 64(6.3)$ & 0.9302 \\
\hline No & $9 / 127(7.1)$ & \\
\hline \multicolumn{3}{|c|}{ Riparian vegetation near residence } \\
\hline Yes & $1 / 16(6.3)$ & 0.6700 \\
\hline No & $12 / 175(6.8)$ & \\
\hline \multicolumn{3}{|l|}{ Native forest near residence } \\
\hline Yes & $1 / 15(6.7)$ & 0.6089 \\
\hline No & $12 / 176(6.8)$ & \\
\hline \multicolumn{3}{|c|}{ Reforested area near residence } \\
\hline Yes & $0 / 8(0)$ & 0.9491 \\
\hline No & $13 / 183(7.1)$ & \\
\hline \multicolumn{3}{|c|}{ Forest areas (square, woods, park) near } \\
\hline Yes & $4 / 12(33.3)$ & \\
\hline No & $9 / 179(5)$ & \\
\hline \multicolumn{3}{|l|}{ Mosquitoes in residence } \\
\hline Yes & $10 / 126(7.9)$ & 0.5753 \\
\hline No & $3 / 65(4.6)$ & \\
\hline \multicolumn{3}{|l|}{ Mosquito Control } \\
\hline Yes & $4 / 42(9.5)$ & 0.6564 \\
\hline No & $9 / 149(6.0)$ & \\
\hline \multicolumn{3}{|c|}{ Ulcerated or nodular epidermal lesions in dog } \\
\hline Yes & $2 / 4(50)$ & 0.0138 \\
\hline No & $11 / 187(5.9)$ & \\
\hline \multicolumn{3}{|l|}{ Lesion site: limbs } \\
\hline Yes & $1 / 2(50)$ & 0.3063 \\
\hline No & $12 / 189(6.3)$ & \\
\hline \multicolumn{3}{|c|}{ Lesion site: tail or whole body } \\
\hline Yes & $1 / 2(50)$ & 0.3063 \\
\hline No & $12 / 189(6.3)$ & \\
\hline \multicolumn{2}{|c|}{$\begin{array}{l}\text { Ulcerated or nodular epidermal lesions in } \\
\text { resident humans }\end{array}$} & 0.08553 \\
\hline Yes & $0 / 1(0)$ & \\
\hline No & $13 / 190(6.8)$ & \\
\hline \multicolumn{3}{|c|}{ Lesion site: legs of resident humans } \\
\hline Yes & $0 / 1(0)$ & 0.08553 \\
\hline No & $13 / 190(6.8)$ & \\
\hline
\end{tabular}

*Endemic area for canine leishmaniasis.

Source: Elaboration of the authors.

\section{Discussion}

In Brazil, the prevalence of Leishmania spp. infection in dogs within urban areas ranges from 4.9 to $13.2 \%$ (MONTEIRO et al., 2005; SERRA et al., 2003). In the state of Paraná, the prevalence varies from $6.7 \%$ (MEMBRIVE et al., 2012) to $56.7 \% \%$
(ZANZARINI et al., 2005) in dogs residing in the rural northern part of the state; the prevalence is 3.1 (DIAS et al., 2013) to 22.8\% (PITTNER et al., 2009) in pet dogs and $26.7 \%$ in stray dogs in other regions of the state (PITTNER et al., 2009). The prevalence is associated with infection by Leishmania species 
responsible for ATL (LONARDONI et al., 2006; MEMBRIVE et al., 2012; PITTNER et al., 2009; REIS et al., 2011; ZULPO et al., 2012) and visceral forms (DIAS et al., 2013; THOMAZ-SOCCOL et al., 2009, 2013) of the disease.

Reis et al. (2011) found 222 (45.4\%) seropositive dogs by IIF among 489 examined in the municipality of Bela Vista do Paraíso, Paraná. None of these animals showed characteristic lesions, which contrasts findings by Madeira et al. (2000) in the region of Itaipu, Rio de Janeiro, where 37 (11.9\%) of 310 dogs participating in a rabies vaccination campaign were positive by IIF. In the present study, $2(50 \%)$ of 4 dogs with ATL lesions were positive by IIF; this variable was significantly associated ( $p$ $=0.0138$ ) with the positive IIF result.

As shown in the present study, environmental factors, such as the presence of organic waste in the yard, have been previously associated with canine infection with Leishmania spp. (REIS et al., 2011) because it enables development of the immature stages of the vector (FORATTINI, 1973). Silva Filho et al. (2012) found similar results in two rural settlements in northern Paraná.

Several studies have shown that proximity to forests is conducive to infection by Leishmania spp. (ALMEIDA et al., 2009; MEMBRIVE et al., 2012; PITTNER et al., 2009; SILVA et al., 2005; SILVA FILHO et al., 2012). Environmental impacts and anthropogenic changes to the environment have allowed the vector to adapt to the peridomiciliary environment and spread disease. In a rural settlement in Mariluz, Paraná, Lonardoni et al. (2006) found a high number of sandflies in and around the home in areas adjacent to managed forests. In the present study, a statistically significant association was found between a positive IIF result and the presence of forest areas (squares, woods, parks) near the residence $(p=0.0015)$. We could not evaluate the association to the presence of native forest because dogs from rural areas were not included.
There was no statistically significant difference associated with the distance between the residence and forest: $25 \mathrm{~m}(\mathrm{p}=0.3542), 25-100 \mathrm{~m}(\mathrm{p}=$ $0.7739)$, and $>100 \mathrm{~m}(\mathrm{p}=0.4065)$. In Arapongas, Paraná, Membrive et al. (2012) observed that a 25 to $100 \mathrm{~m}$ distance between a residence and forest area, up to $25 \mathrm{~ms}$ between a residence and stream, and up to $10 \mathrm{~m}$ between a residence and banana tree orchard were risk factors for ATL in rural dogs. They also found that canine infection increased the risk of human ATL, and certain environmental factors surrounding the home increased the risk of infection in both humans and dogs, which indicates the importance of integrated environmental management measures to avoid contact between humans and sandflies. Falqueto et al. (1986), in a study conducted in Viana, Espírito Santo, also emphasized the relationship between the presence of infected dogs and the occurrence of human ATL.

There was no significant influence of sex, breed, or age on the presence of anti-Leishmania spp. antibodies, which is in agreement with reports by Costa (2011) and Reis et al. (2011) in the northern municipalities of Paraná, and Almeida et al. (2009; 2012) in VL endemic areas in Cuiaba, Mato Grosso. Although these other factors were not significantly associated with the presence of anti-Leishmania spp. antibodies by IIF, they should be considered in future studies of this type because the environmental variables affecting the ecosystem of this zoonotic disease can vary greatly.

No human cases of leishmaniasis have yet been recorded in the municipality of Telêmaco Borba according to the Notifiable Diseases Information System of the Ministry of Health (BRAZIL, 2013). However, physicians should be educated on the need to include ATL as a differential diagnosis in cases of epidermal lesions because the parasite is present in this region. 


\section{Conclusion}

Given the presence of circulating antiLeishmania spp. IgG in the canine population of Telêmaco Borba, Paraná State, prophylaxis and control of mucocutaneous leishmaniasis is recommended. Our results suggest the presence of Leishmania spp. protozoan and its vector in the environment, and indicate the potential for infection in the human population. Health education, such as recommending frequent cleaning of yards to avoid accumulation of organic matter and proper disposal of waste and sewage, should be provided to the general population. Another important preventive measure is to avoid building houses adjacent to woodlands and avoid interchange between the domestic and sylvatic environments, in order to maintain the vector at a distance from humans and animals, especially dogs, which are the link between the wild cycle and peridomiciliary leishmaniasis.

\section{Acknowledgments}

We thank the NGO AMAHTEB (Amigos do Melhor Amigo do Homem de Telêmaco Borba) and the City Hall of Telêmaco Borba for their collaboration, and the Conselho Nacional de Desenvolvimento Científico e Tecnológico (CNPq) for financial support.

\section{References}

ALMEIDA, A. B. P. F.; FARIA, R. P.; PIMENTEL, M. F. A.; DAHROUG, M. A. A.; TURBINO, N. C. M. R.; SOUSA, V. R. F. Inquérito soroepidemiológico de leishmaniose canina em áreas endêmicas de Cuiabá, Estado de Mato Grosso. Revista da Sociedade Brasileira de Medicina Tropical, Uberaba, v. 42, n. 2, p. 156-159, 2009.

ALMEIDA, A. B. P. F.; SOUSA, V. R. F.; CRUZ, F. A. C. S.; DAHROUG, M. A. A. D.; FIGUEIREDO, F. B. F.; MADEIRA, M. F. Canine visceral leishmaniasis: seroprevalence and risk factors in Cuiabá, Mato Grosso, Brazil. Revista Brasileira de Parasitologia Veterinária, Jaboticabal, v. 21, n. 4, p. 359-365, 2012.
ARRUDA, M. M. Leishmanioses. In: Conselho Regional de Medicina Veterinária do Paraná, Santa Catarina e Rio Grande do Sul. Manual de Zoonoses - Programa de Zoonoses Região Sul, v. 1, n. 2, p. 68-90, 2010.

BARROS, G. C.; SESSA, P. A.; MATTOS, E. A.; CARIAS, V. R. D.; MAYRINK, W.; ALENCAR, J. T. A.; FALQUETO, A.; JESUS, A. C. Foco de leishmaniose tegumentar americana nos Municípios de Viana e Cariacica, Estado do Espírito Santo, Brasil. Revista de Saúde Pública, São Paulo, v. 19, n. 2, p. 146-153, 1985.

BRASIL. Ministério da Saúde, Secretaria da Saúde. Leishmaniose visceral - casos confirmados notificados no sistema de informação de agravos de notificação Sinan. 2013. Disponível em: <http://dtr2004.saude.gov. br/sinanweb/tabnet/dh?sinan/leishvi/bases/leishvbr.def $\$$. Acesso em: 02 jul. 2013.

. Ministério da Saúde, Secretaria de Vigilância em Saúde. Guia de bolso: doenças infecciosas e parasitárias. 8. ed. Brasília: Ministério da Saúde, 2010a. 448 p.

. Ministério da Saúde/Secretaria de Vigilância em Saúde. Manual de vigilância da leishmaniose tegumentar americana. 2. ed. Brasília: Ministério da Saúde, 2007. 179 p.

. Ministério da Saúde/Secretaria de Vigilância em Saúde/Departamento de Vigilância Epidemiológica. Manual de vigilância e controle da leishmaniose visceral. Série a: normas e manuais técnicos. Brasília: Ministério da Saúde, 2006. 120 p.

Ministério da Saúde/Secretaria de Vigilância em Saúde/Departamento de Vigilância Epidemiológica. Guia de vigilância epidemiológica. série a: normas e manuais técnicos. 7. ed. Brasília:Ministério da Saúde, 2010b. 24 p.

CASTRO, E. A.; THOMAZ-SOCCOL, V.; MEMBRIVE, N.; LUZ, E. Estudo das características epidemiológicas e clínicas de 332 casos de leishmaniose tegumentar notificados na região norte do Estado do Paraná de 1993 a 1998. Revista da Sociedade Brasileira de Medicina Tropical, Uberaba, v. 35, n. 5, p.445-452, 2002.

CENTERS FOR DISEASE CONTROL AND PREVENTION - CDC. About parasites. 2010. Disponível em: $\quad<$ http://www.cdc.gov/parasites/leishmaniasis/>. Acesso em: 12 set. 2012.

COSTA, D. N. C. C. Avaliação da eliminação canina como estratégia de controle de Leishmaniose Visceral Canina a partir de modelos teóricos de dinâmica de transmissão. 2012. Dissertação (Mestrado em Ciências, na área de Epidemiologia em Saúde Pública) - Escola Nacional de Saúde Pública Sergio Arouca, Rio de Janeiro.

COSTA, L. da. Ocorrência de anticorpos $\operatorname{Ig} G$ anti Leishmania spp. em cães de locais de reciclagem e nas 
adjacências de uma mata urbana de Londrina - PR. 2011. Dissertação (Mestrado em Ciência Animal) Universidade Estadual de Londrina, Londrina.

COUTINHO, S. G.; NUNES, M. P.; MARZOCHI, M. C. A.; TRAMONTANO, N. A survery for Amercian Cutaneous and Viscreal Leishmaniasis among 1.342 dogs from areas in Rio de Janeiro (Brazil) where the human diseases occur. Memórias do Instituto Oswaldo Cruz, Rio de Janeiro, v. 80, n. 1, p. 17-22, 1985.

DANTAS-TORRES, F. Canine leishmaniosis in South America. Parasite \& Vectors, London, v. 2, n. 1, p. S1, mar. 2009.

DIAS, R. C. F.; THOMAZ-SOCCOL, V..; BISETTO JÚNIOR, A.; POZZOLO, E. M.; CHIYO, L.; FREIRE, R. L.; BREGANÓ, R. M.; PASQUALI, A. K. S.; ALBAN, S.; FENDRICH, R. C.; CALDART, E. T.; NAVARRO, I. T. Occurrence of anti-Leishmania spp. antibodies in domiciled dogs from the city of Foz do Iguaçu, State of Paraná, Brazil. In: WORLD CONGRESS ON LEISHMANIASIS, 5., 2013, Porto de Galinhas. Abstract... Porto Galinhas: Sociedade Brasileira de Medicina Tropical, maio 2013, p. 875-876.

FALQUETO, A. Especificidade alimentar de flebotomíneos em duas áreas endêmicas de leishmaniose tegumentar no estado do Espírito Santo. 1995. Tese (Doutorado em Medicina Tropical) - Instituto Oswaldo Cruz. Fundação Oswaldo Cruz, Rio de Janeiro.

FALQUETO, A.; COURA, J. R.; BARROS, G. C.; GRIMALDI FILHO, G.; SESSA, P. A.; CARIAS, V. R. D.; CLAUDINO DE JESUS, A.; ALENCAR, J. T. A. Participação do cão no ciclo de transmissão da Leishmaniose tegumentar no município de Viana, Estado do Espírito Santo, Brasil. Memórias do Instituto Oswaldo Cruz, Rio de Janeiro, v. 81, n. 2, p. 155-163, 1986.

FALQUETO, A.; SESSA, P. A.; VAREJÃO, J. B. M.; BARROS, G. C.; MOMEN, H.; GRIMALDI JUNIOR, G. Leishmaniasis due to Leishmania braziliensis in Espírito Santo state, Brazil: further evidence on the role of dogs as a reservoir of infection for humans. Memórias do Instituto Oswaldo Cruz, Rio de Janeiro, v. 86, n. 4, p. 499-500, 1991.

FORATTINI, O. P. Entomologia médica. São Paulo: Editora Edgar Blucher, v. 4, 1973. 682 p.

GOMES, A. C.; NEVES, V. L. F. C. Estratégia e perspectivas de controle da leishmaniose tegumentar no Estado de São Paulo. Revista da Sociedade Brasileira de Medicina Tropical, Uberaba, v. 31, n. 6, p. 553-558, 1998.

GONTIJO, C. M. F.; MELO, M. N. Leishmaniose visceral no Brasil: quadro atual, desafios e perspectivas.
Revista Brasileira de Epidemiologia, São Paulo, v. 7, n. 3, p. 338, 2004.

INSTITUTO BRASILEIRO DE GEOGRAFIA E ESTATÍSTICA - IBGE. Cidades, Paraná, Telêmaco Borba. 2012. Disponível em:<http://www.ibge.gov.br/ cidadesat/topwindow.htm?1>. Acesso em: 14 nov. 2012.

INSTITUTO PARANAENSE DE DESENVOLVIMENTO ECONÔMICO E SOCIAL - IPARDES. Caderno estatístico de Telêmaco Borba. Curitiba: Instituto Paranaense de Desenvolvimento Econômico e Social, jun. 2012. Disponível em: $<$ http://www.ipardes.gov.br/cadernos/ Montapdf.php?Municipio $=84260 \& \mathrm{btOk}=\mathrm{ok}>$. Acesso em: 13 nov. 2012.

LONARDONI, M. V. C.; SILVEIRA, T. G. V.; ALVES, W. A.; MAIA-ELKHOURY, A. N. S.; MEMBRIVE, U. A.; MEMBRIVE, N. A.; RODRIGUES, G.; REIS, N.; ZANZARINI, P. D.; ISHIKAWA, E.; TEODORO, U. Leishmaniose tegumentar americana humana e canina no Município de Mariluz, Estado do Paraná, Brasil. Caderno de Saúde Pública, Rio de Janeiro, v. 22, n. 12, p. 2713-2716, 2006.

MADEIRA, M. F.; SERRA, C. M. B.; UCHÔA, C. M. A.; DUARTE, R.; CRUZ, D. A. M.; PERDOMO, C. C. Leishmaniose canina: avaliação sorológica de 310 cães na região de Itaipu, Rio de Janeiro. Caderno de Saúde Pública, Rio de Janeiro, v. 16, n. 2, p. 568-568, 2000.

MARZOCHI, M. C. de A.; MARZOCHI, K. B. F. Tegumentary and visceral Leishmaniases in Brazil emerging anthropozoonosis and possibilities for their control. Caderno de Saúde Pública, Rio de Janeiro, v. 12, n. 2, p. 359-375, 1994.

MEMBRIVE, N. A.; RODRIGUES G.; GUALDA, K. P.; BERNAL, M. V. Z.; OLIVEIRA, D. M.; LONARDONI, M. V. C.; TEODORO, U.; TEIXEIRA, J. J. V.; SILVEIRA, T. G. V. Environmental and animal characteristics as factors associated with american cutaneous Leishmaniasis in rural locations with presence of dogs, Brazil. PLoS ONE, San Francisco, v. 7, n. 11, p. e47050, 2012.

MONTEIRO, E. M.; SILVA, J. C. F.; COSTA, R. T.; COSTA, D. C.; BARATA, R. A.; VIEIRA DE PAULA, E.; MACHADO-COELHO, G. L.; ROCHA, M. F.; FORTES-DIAS, C. L.; DIAS, E. S. Leishmaniose visceral: estudo de flebotomíneos e infecção canina em Montes Claros, Minas Gerais. Revista da Sociedade Brasileira de Medicina Tropical, Uberaba, v. 38, n. 2, p. 147-152, 2005.

OLIVEIRA, T. M. F. S.; FURUTA, P. I.; CARVALHO, D.; MACHADO, R. Z. A study of cross-reactivity in serum samples from dogs positive for Leishmania sp., Babesia canis and Ehrlichia canis in enzyme-linked 
immunosorbent assay and indirect fluorescent antibody test. Revista Brasileira de Parasitologia Veterinária, São Carlos, v. 17, n. 1, p. 7-11, 2008.

PESSÔA, S. B.; MARTINS, A. V. Gênero Leishmania; Leishmania donovani/Leishmaniose visceral ou calazar. In: _. Parasitologia médica. 11. ed. Rio de Janeiro: Guanabara Koogan, 1988. p. 67-77.

PITTNER, E.; VOLTARELLI, E.; PERLES, T. F.; ARRAES, S. M. A. A.; SILVEIRA, T. G. V.; LONARDONI, M. V. C. Ocorrência de leishmaniose tegumentar em cães de área endêmica no Estado do Paraná. Arquivo Brasileiro de Medicina Veterinária e Zootecnia, Belo Horizonte, v. 61, n. 3, p. 561-565, 2009.

REIS, H. R.; LOPES-MORI, F. M. R.; REIS, C. R.; FREIRE, R. L.; MARANA, E. R. M.; CHRYSSAFIDIS, A. L.; TEDIM, A. V.; RUFFOLO, B. B.; BUGNI, F. M.; CASTRO, E. A.; THOMAZ-SOCCOL, V.; NABUT, L. B.; NAVARRO, I. T. Soroprevalência da Leishmaniose Tegumentar Americana (LTA) canina e fauna de Flebotomíneos (Diptera: Psychodidae) em Bela Vista do Paraíso, Paraná. Semina: Ciências Agrárias, Londrina, v. 32, n. 3, p. 1083-1094, 2011.

ROMERO, G. A. S.; BOELAERT, M. Control of visceral Leishmaniasis in Latin America - a systematic review. PLoS Neglected Tropical Diseases, San Francisco, v. 4, n. 1, p. e584, 2010.

SERRA, C. M. B.; LEAL, C. A.; FIGUEIREDO, F.; SCHUBACH, T. M.; DUARTE, R.; UCHÔA, C. M. A.; SILVA, R. M. M.; MADEIRA, M. F. Leishmaniose tegumentar canina em Morada das Águias (Serra da Tiririca), Maricá, Rio de Janeiro, Brasil. Caderno de Saúde Pública, Rio de Janeiro, v. 19, n. 6, p. 877-1880, 2003.

SILVA FILHO, M. F.; TAMEKUNI, K.; TOLEDO, R. S.; DIAS, R. C. F.; LOPIS-MORI, F. M. R.; BREGANÓ, R. M.; THOMAZ-SOCCOL, V.; GARCIA, J. L.; FREIRE, R. L.; VIDOTTO, O.; NAVARRO, I. T. Infection by Toxoplasma gondii and Leishmania spp. in humans and dogs from rural settlements in Northern Paraná State, Brazil. Semina: Ciências Agrárias, Londrina, v. 33, n. 2, p. 3251-3264, 2012.

SILVA, A. V. M.; PAULA, A. A.; CABRERA, M. A. A.; CARREIRA, J. C. A. Leishmaniose em cães domésticos: aspectos epidemiológicos. Caderno de Saúde Pública, Rio de Janeiro, v. 21, n. 1, p. 324-328, 2005.

TELÊMACO BORBA - PREFEITURA MUNICIPAL - ASSESSORIA TÉCNICA DE PLANEJAMENTO URBANO. Plano diretor de desenvolvimento de Telêmaco Borba. nov. 2005. Disponível em: <http:// www.telemacoborba.pr.gov.br/plano_diretor/ Analise \%2520Tematica/perfil\%2520(completo). pdf + pluviosidade + telemaco + borba\&cd $=1 \&$ hl $=$ pt BR\&ct $=$ clnk\&gl=br $>$. Acesso em: 14 nov. 2012.

TEODORO, U.; LA SALVIA FILHO, V.; LIMA, E. M.; SPINOSA, R. P.; BARBOSA, O. C.; FERREIRA, M. E. M. C.; SILVEIRA, T. G. V. Flebotomíneos em área de transmissão de leishmaniose tegumentar na região norte do Estado do Paraná - Brasil: variação sazonal e atividade noturna. Revista de Saúde Pública, São Paulo, v. 27, n. 3, p. 190-194, 1993.

THOMAZ-SOCCOL, V.; LUZ, E.; BISETTO JUNIOR, A.; CASTRO, E. A.; FERREIRA DA COSTA, E. S.; NAVARRO, I. T. Visceral and Cutaneous Leishmaniasis in the Paraná State, Southern of Brazil border with Argentina and Paraguay. In: WORLD CONGRESS ON LEISHMANIASIS, 5., 2013, Porto de Galinhas. Abstract... Porto Galinhas: Sociedade Brasileira de Medicina Tropical, maio 2013. p. 76-77.

THOMAZ-SOCCOL, V.; CASTRO, E. A.; NAVARRO, I. T.; FARIAS, M. R.; SOUZA, L. M.; CARVALHO, Y.; BISPO, S.; MEMBRIVE, N. A.; MINOZZO, J. C.; TRUPPEL, J.; BUENO, W.; LUZ, E. Casos alóctones de leishmaniose visceral canina no Paraná, Brasil: implicações epidemiológicas. Revista Brasileira de Parasitologia Veterinária, Jaboticabal, São Paulo, v. 18, n. 3, p. 46-51, 2009.

WORLD HEALTH ORGANIZATION - WHO. Health surveillance and disease prevention and control area communicable diseases prevention and control project Leishmaniasis. WHO/PAHO. abr. 2012. Available at: $<$ http://new.paho.org/hq/index.php?option=com_content $\&$ view $=$ category \&layout $=$ blog $\&$ id $=3835 \&$

Itemid $=4098 \&$ lang $=$ en $>$. Accessed at: 12 set. 2012.

Control of the leishmaniasis: report of a meeting of the WHO Expert Committee on the Control of Leishmaniases. WHO technical report series, n. 949 Geneva: World Health Organization, 22-26 mar. 2010. $200 \mathrm{p}$.

ZANZARINI, P. D.; SANTOS, D. R.; SANTOS, A. R.; OLIVEIRA, O.; POIANI, L. P.; LONARDONI, M. V. C.; TEODORO, U.; SILVEIRA, T. G. V. Leishmaniose tegumentar americana canina em municípios do norte do Estado do Paraná, Brasil. Caderno de Saúde Pública, Rio de Janeiro, v. 21, n. 6, p. 109-118, 2005.

ZULPO, D. L.; LEITE, J. H. A. C.; CUNHA, I. A. L.; BARROS, L. D.; TARODA, A.; CAMARGO JÚNIOR, V. E.; SANTOS, H. L. E. P. L.; GARCIA, J. L. Ocorrência de anticorpos contra Leishmania spp., Neospora caninum e Toxoplasma gondii em soros de cães atendidos no Hospital Veterinário da Universidade Estadual de Londrina-PR. Semina: Ciências Agrárias, Londrina, v. 33, n. 5, p. 1897-1906, 2012. 